\title{
Increased prevalence of Plasmodium falciparum malaria in Honduras, Central America
}

\author{
Carol J. Palmer, ${ }^{1}$ Michael Makler, ${ }^{2}$ Winslow I. Klaskala, ${ }^{1}$ \\ John F. Lindo, ${ }^{3}$ Marianna K. Baum, ${ }^{1}$ and Arba L. Ager ${ }^{1}$
}

ABSTRACT We report on our investigation of a malaria outbreak in Honduras, Central America, in January 1997. We tested 202 patients with fever and chills using thin and thick blood film microscopy. Sixteen patients lived in the city and the rest lived in rural areas. A total of 95 samples $(47 \%)$ were positive for malaria parasites. Seventy-nine percent (63/80) of the rural patients were infected with Plasmodium vivax and $21 \%(17 / 80)$ were infected with $\mathrm{P}$. falciparum. In the urban area, all 15 infected patients had P. vivax malaria and none showed evidence of P. falciparum. Since previous reports indicate that falciparum malaria accounts for only $2 \%$ of the overall malaria infections in Honduras, the results reported here suggest that there is a dramatic increase in falciparum malaria in the area of Honduras investigated in this study.

Malaria is a significant cause of morbidity and mortality worldwide. Every year malaria parasites infect an estimated 300-500 million people and cause more than 2.7 million deaths (1). Over the past few years there has been a striking increase in malaria in Honduras, Central America. The number of reported cases in the country rose sharply from 52110 in 1994, to 59446 in 1995, and to 75565 in 1996 (2, 3). This

\footnotetext{
1 University of Miami, School of Medicine, Miami, Florida, USA. All correspondence and requests for reprints should be sent to Carol J. Palmer at the following mailing address: Division of Infectious Diseases, University of Miami, School of Medicine, Center for Disease Prevention, 1400 NW 10th Avenue, 10th floor (D21), Miami, Florida 33136, USA. Tel: 305-243-3221; Fax: 305-243-4687.

2 Flow Inc., Portland, Oregon, USA.

3 University of the West Indies, Kingston, Jamaica.
}

represents a $45 \%$ increase in malaria cases over the three-year period.

Plasmodium vivax is reported to be the infecting strain in approximately $98 \%$ of Honduran malaria cases. The remainder are caused by $P$. falciparum, which is associated with a much more severe form of disease (2-4). However, we recently documented a much higher proportionate incidence of falciparum malaria in northern Honduras.

In January 1997, we investigated a malaria outbreak in the Colón region of northern Honduras. The landscape there ranges from coastal lowlands to lush mountains. When employed, people work mainly in agricultural jobs, such as banana farming. The average monthly income is about US\$ 25-50. Along with the outbreak, we also tested individuals living in the city of
San Pedro Sula, a large urban center located approximately 400 miles east of the rural area. Although urban incomes are slightly higher than rural, most people still live in poverty.

A total of 202 blood samples, 186 at a local rural health clinic and 16 house-to-house in remote areas of the city, were collected from individuals with symptoms suggesting malaria (fever and chills). Thick and thin blood films were made on site from all patient blood specimens. Blood film slides were transported the next day to the University of Miami School of Medicine, where they were read by an individual with over 30 years of experience in interpreting malaria blood films. Since it is common practice in this area of Honduras to provide symptomatic patients with antimalaria 
treatment prior to laboratory diagnosis, all patients were given a 3-day supply of chloroquine (500 $\mathrm{mg}$ ) and were instructed to return in 4 days for additional chloroquine if they remained ill.

Of the samples, $47 \%(95 / 202)$ were positive for malaria parasites. $P$. vivax was present in $79 \%(63 / 80)$ of the infected rural patients and 100\% (15/15) of the infected city patients. P. falciparum was present in $21 \%(17 / 80)$ of the rural patients. No patient was infected with both strains. The individuals positive for falciparum malaria ranged in age from 5-41 years and averaged 20 years. Those positive for vivax malaria ranged from 4-50 years of age. Their average age was 16 , four years younger than the falciparum malaria group. National surveillance data, which are actively collected within Honduras, indicate that most falciparum malaria occurs in the Colón region. However, in 1996, P. falciparum accounted for only $3.5 \%$ of the malaria cases in this area $(2,3)$. Results from our investigation demonstrate that $P$. falciparum parasites were associated with $22 \%$ of the malaria cases, which represents a significant increase in $1997\left(P<0.0001 ; \chi^{2}=284.6\right)$.

Possible explanations for the observed rise in $P$. falciparum malaria are:
- Increased vector transmission. In 1997 the rainy season, which is also the mosquito season, was unusually long. This may have contributed to increased vector transmission in this area.

- An increase in humans infected for the first time (nonimmune population). Although no information is available on Hondurans' immunity to malaria, the disease is considered endemic in the country. Seventy-one percent of the population lives within malarial areas, suggesting that a large portion of the population has already been exposed to malaria and hence that nonimmune populations were not a factor in this increase (4).

- Development of chloroquine resistance by $P$. falciparum parasites. Chloroquine is routinely distributed to all patients in the area of the outbreak. There was no clinical follow-up to see if the recommended treatment was completed or to determine patient outcome. Anecdotal information indicates that compliance to chloroquine chemotherapy in the study area is low, suggesting that suboptimal levels of antimalarials are taken. Suboptimal drug levels in combination with the extensive use of single-drug therapy regimens may lead to the development of chloroquine resistance in Plasmodium species circulating in Honduras. The last reported survey for chloroquine resistance in Honduras dates back to 1981 (5). It indicated that resistant strains were not present, but new studies are clearly needed, especially since recent reports in the literature indicate that drug failures from both primaquine and chloroquine are increasing worldwide (6-9).

- Underdiagnosis of falciparum malaria.

The widespread development of drug resistance by $P$. falciparum poses a formidable challenge to controlling and containing the disease in infected individuals. Based on our results and the escalation of malaria cases in Honduras, we strongly recommend increased laboratory testing for accurate identification of malaria parasites and enhanced surveillance for chloroquine resistance.

Acknowledgments. This study was supported by Fogarty grant 5D43TW00017-08 and Department of Defense SBIR grants $1794 \mathrm{C} 4037$ and 1797 C7022.

\section{REFERENCES}

1. Nussenzweig RS, Zavala F. A malaria vaccine based on a sporozoite antigen. New Engl J Med 1997;336:128-130.

2. Pan American Health Organization. Malaria in the Americas. Epidemiol Bull 1996;71:1-6.

3. Honduras, Ministry of Health. Internal surveillance report. Tegucigalpa, Honduras: HMH; 1997.

4. Dourado HV, Abdon NP, Martins SJ. Falciparum malaria. Infect Dis Clin North Am 1994; 8:207-223.

5. Nguyen-Dinh P, Hobbs JH, Campbell CC. Assessment of chloroquine sensitivity of Plasmod- ium falciparum in Choluteca, Honduras. Bull World Health Organ 1981;59:641-646.

6. Krogstad DJ. Malaria as a reemerging disease. Epidemiol Rev 1996;18:77-89.

7. Doherty JF, Day JH, Warhurst DC, Chiodini PL. Treatment of Plasmodium vivax malaria: time for a change. Trans $\mathrm{R}$ Soc Trop Med Hyg 1997;91:76.

8. Longworth DL. Drug-resistant malaria in children and in travelers. Pediatr Clin North Am 1995;42:649-664.

9. Wernsdorfer WH, Landgraf B, Wiedermann F, Kollaritsch H. Chloroquine resistance of Plas- modium falciparum: a biological advantage. Trans R Soc Trop Med Hyg 1995;89:90-91.

Manuscript received on 26 June 1997. Revised version accepted for publication on 31 March 1998. 
RESUMEN Notificamos los resultados de un estudio de un brote de malaria que se produjo en Honduras, Centroamérica, en enero de 1997. Sometimos a examen microscópico frotis delgados y frotis gruesos de la sangre de 202 pacientes con fiebre y escalofríos. Dieciséis pacientes eran habitantes de la zona urbana y el resto de la zona rural. Un total de 95 especímenes (47\%) fueron positivos a parásitos de la malaria. Setenta y ocho por ciento $(62 / 80)$ de los pacientes del área rural estaban infestados con Plasmodium vivax y $22 \%(17 / 80)$ con $P$. falciparum. En la zona urbana, todos los 15 pacientes que estaban infestados tenían $P$. vivax y en ninguno se detectó $P$. falciparum. Ya que según informes previos la malaria de tipo falciparum representa solamente $2 \%$ de todos los casos de malaria en Honduras, nuestros resultados sugieren que hay un gran incremento del número de casos de malaria falciparum en la zona de Honduras

falciparum en Honduras, Centroamerica en que se llevó a cabo esta investigación.

\footnotetext{
\begin{tabular}{l} 
Appreciation note for the Caribbean Development Bank \\
\hline In recognition that the most important tool in health promotion is information, the \\
Caribbean Development Bank donated, through the PAHO country office in Barbados, 500 \\
copies of PAHO Scientific Publication No. 561, Health Conditions in the Caribbean, published \\
in 1997. As a result, health workers in the public sector at the regional, national, and local lev- \\
els now have access to this important tool. Because the book is so useful to government insti- \\
tutions, the Bank's generosity is most appreciated. \\
Health Conditions in the Caribbean, the first and only comprehensive report dealing with \\
the health situation in Caribbean countries, covers the overall health status and the social, eco- \\
nomic, and political context of this subregion's population. In addition, it describes each coun- \\
try's progress in the important health program areas of maternal and child health, food and \\
nutrition, control of noncommunicable diseases, and injuries, AIDS prevention and control, and \\
environmental protection. It cites examples of how the countries have responded to health \\
issues over the years and gives information about the current health strategies.
\end{tabular}
} 